\title{
A Threat to National Security: The Case of Boko Haram in Nigeria
}

\author{
Peterside, Brown Zainab \\ Federal University Lokoja, Nigeria. \\ Email: zainabpeterside@gmail.com
}

\section{Doi:10.5901/ajis.2014.v3n4p283}

\begin{abstract}
Nigeria has been bedeviled by ethno-religious conflicts with both devastating human and material consequences since the return of democracy in 1999. The current terrorist insurgency by the Northern-based Boko Haram group has continued to pose a serious threat to Nigeria's security and corporate political entity. This is evidenced in the group's undeterred spate of terrorist attacks on citizens, the nation's security personnel, wanton destruction of lives and property. This paper will focus on the assessment of the Boko Haram's unprecedented campaign of terror that is growing both in number and brutality that has constituted itself as a national security threat to the continual and harmonious co-existence of the component nations that make up the Nigerian state.
\end{abstract}

Keywords: Boko Haram, Security, Terrorism, Insurgency, Threat

\section{Introduction}

The quest for security is no doubt, a known primary concern of every political community from time immemorial. Indeed, "the search for security might have been one of the several drives for people to aggregate into bands, tribes, kingdoms and nation-states to join international organizations" (PadelFord, 1976:182).

During the early stages of man's existence, the quest for security was given expression in form of fruit gathering and periodic hunting expedition for the purposes of meeting the basic socio-economic requirements of the people. Also, people's preference for a rocky and mountainous topography as shelter was largely informed by physical security consideration. Similarly, the practice of building fortifying walls around residential structures was largely motivated by the security need of the people (Gambo, 2008:1). However, modern society has witnessed far reaching transformation which has created complicated security problem for it.

After decades of dictatorship, Nigeria's return to democracy in 1999 is been threatened by the unprecedented campaign of terror by a terrorist group called Boko Haram whose activities are threatening to engulf a huge swathe of the country. In sum, persistent insecurity confined hitherto to three or four states is fast spreading. As lawlessness holds sway, the entire north is turning into a huge killing field.

\section{Conceptual Clarifications}

The English word "security" originates from the Latin word "Se-curus". "Se" means "without' and "curus" means "uneasiness". That implies that 'security' originally meant liberation from uneasiness, or a peaceful situation without any risks or threats. The English word "security" has a wider range of meaning including "to feel safe", and "to be protected", and is used to describe a situation without any risks or worries (Mesjasz, 2004).

The concept 'security' generally is a crosscutting and multi-dimensional concept which has over the last century been the subject of great debate. Security has been seen as a situation where a person or thing is not exposed to any form of danger or risk of physical or moral aggression, accident, theft or deterioration. Some security experts argued that the concept of security has always been associated with the safety and survival of the state and its citizens from harm or destruction or from dangerous threats. This conception generally holds that the state is the only institution with the primary responsibility and power for the safety of its territory and its people (Zabadi, 2005:3).

\section{Conceptual Framework of Analysis}

Security is arguably, something desired by all. The enduring quest for security is in fact, inherent in man and constitutes 
the primary concern of any responsible government (Ivor, 1996:65). Buzan (1992:2) argued that the "concept of security is underdeveloped". The concept of security is generally believed to be complex. Thus the character of security is essentially a contested one hence it has defied an agreed definition as can be observed from the definition of numerous scholars.

Two major perspectives on security can be discerned from available literature on the subject. These are: classical or conventional and revisionist or new thinking perspective (Imobige, 1992; Buzan, 1992). These two contending perspectives only support Buzan's (1992) argument on the need to "habilitate" the concept of security because of its inadequate conceptualization and articulation. While the classical or conventional perspective equates security with massive military build-up, the revisionist or new thinking perspective is socially based with strong emphasis on the desire to utilize the available resources of any nation to meet enduring welfare ends of the citizenry.

At this juncture, let us now examine in detail, the arguments of these two perspectives on security in order to appreciate the extent of their divergence or convergence with respect to the meaning and understanding of security.

The classical or conventional perspective on security is rooted in the state-centric view of International Relations. States as the key actors in international relations are believed by proponents of this view to operate in a system that is devoid of a well structured and centralized political authority. Walt (1979) stresses the point that the anarchical nature of the international system makes it a matter of practical necessity for states to look out for their protection and survival in the system. He describes the system as a 'self-help' system in which each state must take adequate and effective measures to provide for its own security largely conceived in terms of territorial integrity, independence and sovereignty. Proponents of this perspective argue that nation-states compete for many of the same thing including self- preservation, national identity, sovereignty, status and wealth which are acutely scarce.

It is therefore, the acute scarcity of these identified values in the preceding that provides strong motivation for sovereign states to amass as much military power as they can. Security in this context is largely perceived as a function of power and that power is a demonstrable function of awesome military capability. States are believed to have unfaltering faith in the efficacy of "build up of strong military defence as a means of protecting the territorial or national integrity of the state from both internal and external violations" (Imobige, 1998:14).

This militaristic thinking on the concept of security could be traced to the post World War II when the United States of America and the then Soviet Union were almost inextricably locked up in ideological conflict which came to be known as East-West cold war. While the United States of America was determined to, not only shield the capitalist bloc but also expand its frontiers, the Soviet Union was also seeking to construct a vast sphere of influence for the Socialist bloc. This ideological schism in the Western part of the globe ignited arm-race between the two blocs.

It is important to stress the point that the 'classical' or 'conventional' perspective of security focuses exclusively on the state and security is measured by the military capabilities of nation-states. This notion of security gives the state the wide latitude to clamp down on its citizens even when objective conditions call for mass protest against certain unprogressive programmes being implemented in most third world societies. This is because the realist view of security equates it with regime survival and therefore anything that threatens the internal coherence and strength of the state must be hurriedly tackled using the most effective instruments of coercion available. This however, does not promote mutual progressive relationship between the state and the citizenry.

Exclusive focus on the security of the state while neglecting human security has proved to be counter- productive in the long run. Widespread social unrest and violence in many developing societies is a potent indicator that security cannot be defined exclusively in military terms (Gambo, 2008:22).

The revisionist or new thinking perspective stresses the non-military aspects of security. It seeks to reconstruct the concept of security in a more inclusive sense. The new thinking perspective emerged with the collapse of the Soviet Union in 1989. Since the cold war was the basis for the militaristic conception of security, its demise has consequentially cast a dark shadow of doubt upon the strategic relevance of security through build-up of a formidable military defence. This perspective is evidently a post-cold war peace dividend which seeks to redirect efforts towards expanding the frontiers of human-centered development. It argues that the security of any nation is best guaranteed by utilizing disproportionate amount of its available resources to attain enduring welfare ends of the citizens (Imobighe, 1998).

Proponents of the revisionist or new thinking perspective on security (Imobighe, 1998; Buzan, 1992; Galtung, 1982) contend that the militaristic notion of security largely dictated by the cold war phenomenon, has lost its soul with the demise of the cold war. Emphasis in articulating a more inclusive notion of security is placed on building a well contented, prosperous, freer and fulfilled citizenry radiating with happiness.

The notion of security as articulated by the proponents of new "thinking" or 'revisionist' perspective' includes the ability of a social entity for self-protection, development and the enhancement of the general well-being of the people 
(Imobighe, 1998). It is this ability to attain the enduring welfare ends of the citizens by the state that cultivates in them, the feeling of patriotism and deeper commitment to the security of the state. Security in this sense means the capacity of groups to provide for their physical and psycho-social needs and livelihoods.

The point of divergence between the classical or conventional and revisionist or new thinking perspective on security is that the latter has shifted focus from the state centric and militaristic conception of security as held by the former, to human-centered notion of security. The human security perspective asserts that the security of the state is not an end in itself but rather, it is a means of ensuring security for its people. In this context, state security and human security are mutually supportive.

This view is supported by Gurt (1985) when he argues that for a state to feel secure, it has to worry more about "its immediate strategic and political environment because the range of possible threats to, or infringement on its independence and security, encompasses many non-military actions as well" (Gurt, 1985:131). In other words, the security of any social system is not necessarily a function of its military power but essentially the aggregate of both military and non-military factors.

Similarly, Imobighe (1998) conceptualizes security as not only the elimination of threat to physical existence of the state, but more importantly the ability to shield its citizenry against the agonies of lack of development. Imobighe has preference for socio-economic and political viability as guaranteeing security.

Robert McNamara (1968) in a similar vein cautions against heavy reliance on the military as a means of ensuring security in a modernizing society. He argues that: in a modernizing society, security means development.

Security is not military force though it may involve it. Security is not traditional military activity though it encompasses it. Security is not military hardware, though it may include it. Security is development and without development, there can be no security (1968: 149).

McNamara's view of security is possibly on the fact that modernizing societies are usually characterized by weak and fragile economic base which can hardly sustain any serious military offensive. Such modernizing societies are also technologically impotent and this makes them spend a great deal of their scarce but allocatable resources on acquisition of military hardware from advanced countries. Exclusive focus on military security to the total neglect of human security expressed in socio-economic development of the citizenry amounts to what Renner (1990:181) refers to as "dismantling a house to salvage the materials to erect a fence around it". McNamara (1968:115) captures this point more poignantly: any society that seeks to achieve adequate military security against the background of acute food shortage,population explosion, low level of productivity and per-capita income, a high rate of illiteracy, a fragile infrastructural base for technological development, inadequate and inefficient public utilities and a chronic problem of unemployment has a false sense of security.

However, given the multiplicity of views that characterize the concept of security, it becomes onerously tasking for one to synthesis the divergent views to come up with a working definition of the concept. Though as Robert McNamara underscores the point that the nature of an individual state's security varies with their level of development, we must appreciate the fact that certain common objective factors like national stability, internal social cohesion, strong economic base, well discipline and cohesive military formation, environmental stability, e.t.c. constitute the credible and enduring foundation upon which the value of national security is predicated. We may therefore advance a thesis that a nation's security is the expression of its confidence to enjoy the support and loyalty of its citizenry both in time of peace and national emergency which could only be guaranteed through meeting the basic essentials of the people. This invariably means that the government of any nation that cannot meet up the basic needs of its citizenry can hardly count on their support when it is at war with an adversary. The government of a state that is perceived as insensitive and unresponsive to the needs and aspirations of her people, is more predisposed to pursue with maximum vigour, the security of the regime in power rather than focusing on the primacy of collective interest.

In today's world, it must be re-echoed that the increasing role of the economy and finance is considered that in economic terms security is a "public good" which provides benefits to all members of a community as soon as it is made available to any one person. Such a good is collectively consumed by everyone in a community, and it is impossible to charge for its use. This was corroborated by the United Nations when it asserted that:

The concept of security must change from an exclusive stress on national security to a much greater stress on people's security,from security through armaments to security through human development, from territorial security to food, employment and environmental security (Human Development Report 1993-www.undp.org/hdro/e.93over.htm).

Having dwelt extensively on conceptualization of security, it's time we move on to the second aspect of the paper which is the issue of Boko Haram. 


\section{The Origin of Boko Haram in Nigeria}

"Boko Haram" is a militant group that is domicile in the Northern part of Nigeria and its activities came to limelight after the 2011 general elections in which the current president emerged as the winner.

The Boko Haram militant group has been in existence right from the 1960s but only drew attention in 2002. There are evidences that the group has been operating under the name of Shabaab Muslim Youth Organization with Mallam Lawal as the leader since 1995 but the leadership changed to Mallam Mohammed Yusuf following the formers educational pursuit in Saudi Arabia (Ekanem, Dada, \& Ejue, 2012:232). It is also on record that it was the leadership of Mallam Mohammed Yusuf that opened up the group to political influence and thus can be said to be the official founder in 2002 in the city of Maiduguri with the aim of establishing Sharia government in Borno and neighbouring states.

The official name of the Boko Haram group is 'Jama'atu Allis Sunna Lidda'awit wal-jihad' which in Arabic language means "People of the way of Prophet Muhammed (Peace be on to him) and community (of Muslims) in line with the earlier generation of Muslims' and not Boko Haram which simply means 'Western secular education is Islamically prohibited'. Boko Haram has also been defined to mean that evangelism deceptively camouflage as western education is islamically unacceptable (DCCN, 2009:2). It is also worthy of note that the origin of the name "Boko Haram" have been traced to Media and Public Community coinage (DCCN, 2009:2).

Another version to the origin of the sect according to one Umar Mamodu; a scholar and a key Boko Haram historian is that, the sect emerged in 2002 as a result from a clash between the moderate Islamic teachings of the prominent Sheikh Jafar Adam at the Mohammadu Ndimi Mosque in Maiduguri and the more militant interpretation of the Qur'an by his disciple Yusuf. According to the same source, Yusuf believed in the creation of a new order in which the wretched should inherit the earth, and his extremist views, was responsible for him being expelled in 2002 from the Ndimi Mosque Committee. Later that same year, Yusuf built a mosque to serve as a magnet for primary and secondary school pupils who in response to his teachings, would abandon westernized schools in the belief that western education (Boko) is a sin (Haram) hence the name Boko Haram (Owalade 2014).

Another version of the origin of the Boko Haram group is said to be founded in 2002 in Maiduguri, the capital of Borno state by Mallam Mohammed Yusuf. In 2004 it moved to Kanamma in Yobe state where it set up a camp called "Afghanistan", from where it launched attacks on nearby police outposts killing police officers.

From the aforementioned origins of the Boko Haram, one thing that is conspicuously clear is the fact that the group was founded by the late Mallam Mohammed Yusuf and the official name has remained the same.

\section{Boko Haram a Threat to National Security}

Boko Haram was a little understood, dangerous but parochial sect believed to be in decline after a purge by the Nigerian security forces in 2009. In July same year, the Nigerian Police began investigating the group following reports that the group was arming itself. Based on that, several of its leaders were arrested in Bauchi state which sparked up deadly clashes with the Nigerian security forces that resulted in the death of over 700 people (www.wikipedia.com).

On 30 July 2009, another clash between the group and security forces was witnessed in Maiduguri city in which Mohammed Yusuf was arrested and it was later alleged that he was killed after been taken into police custody (Wikipedia).

Years later, the group has remain little understood and has evolve into Nigeria's most serious security threat, one which shows no sign of abating inspite of governments repeated line that it is solving the problem. Since the Boko Haram crises emerged a few years ago, there have been conflicting versions about who they are and where they are going. The versions are many that one has lost count. One version says that the insurrection got worse in retaliation of the killing of their leader-Mohammed Yusuf. Another version says it is an attempt by some Northern politicians to make President Jonathan's tenure miserable. There is yet another version that alleges that the group is sponsored by Jonathan himself to make Northern Nigeria ungovernable so that elections will not hold there come 2015. There is yet another version that points at the security agencies and also accused them of ineptitude; and another that suggests the infiltration of security agencies by the sympathizers of the insurgents (The Punch Newspaper, 2014:22).

In pursuit of their objectives, the Boko Haram group engages in bombing churches, Mosques, Police stations, Schools, Universities, Government properties as well as private ones. They also engage in the killing, kidnapping and slaughtering of innocent souls which has led to the death of large number of their captives. The group activities involve the use of suicide bombers and the burning of everywhere they set their foot on leaving behind trail of woes. Their initial pattern made the Christians and their worship centres the major target, then the Muslims and the mosques also became 
targets, yet there is now a new trend that makes anyone and everyone their target, whether Muslim or Christian. They initially targeted government agencies and the police, later international organizations like the UN building, then schools, media outfits, and other sources of 'haram'. Today, the insurgents have changed as they have considerable number of Christians and traditional worshippers among them and as such cannot be seen as an Islamic terrorist thus this paper sees them as an evil group, who no one knows where they will go next.

It is our view that the Boko Haram group has carried out more atrocities than any other insurgent group in our Nation and that this is also the worst calamity that has befallen our nation since the civil war.

Corroborating this, Emmanuel Oladesu (The Nation Newspaper, 2013:4) stated thus: Since the end of the civil war no calamity of enormous proportion has befallen the fledging nation-state more than the horror unleashed by the dreadful Boko Haram sect. Many lives have been lost, properties worth billions of naira have also been destroyed. Nobody is insulated from the attack, government officials and buildings, traditional rulers, police and military formations and church worshippers are targets. On daily basis, there is panic. The fear of the invincible agitators has become the beginning of wisdom.

This was the situation of things until $28^{\text {th }}$ January 2013 when the sect announced a temporary ceasefire through one of its leader Sheikh Mohammed Abdulazeez Ibn Idris (The Nation Newspaper 2013:1) which was later countered to be untrue by another member of the group. It is also worthy of mention that the Federal Government of Nigeria have offered members of Boko Haram amnesty which was out rightly rejected by them and that committees have been set up at both federal and state levels for the purpose of bringing to an end the activities of this group to no avail.

The trend goes this way; In January 2010, the group struck in Borno, killing four people in Dala Alemderi ward of Maiduguri metropolis.

On September 7 2010, the Boko Haram sect attacked and freed over 700 inmates from a prison in Bauchi state.

In December 2010, the Boko Haram sect was blamed for a market bombing in Maiduguri .

On Christmas Eve, 2010, half a dozen bombs were detonated near churches and markets in Jos killing scores of people.

Similarly, the New Year eve 2010 bombing where a bomb was detonated in a popular open- air fish market inside Mogadishu barracks outside Abuja killed over 25 people.

On Friday January 28, 2011, a gubernatorial candidate was assassinated along with his brother and four police officers in a Mosque premises.

The June 162011 bombing of the Nigerian Police Headquarter in Abuja, was a strategic one and also their first outing outside the north east zone, the then Inspector General of Police Hafiz Ringim had just returned from a tour of Maiduguri where the sect had just carried out an attack and he promised to smoke them out. Security officials believed that was the first suicide bombing in Nigeria's history and the IG was believed to be the principal target.

The sect followed up with the bombing of the UN house on August 262011 in Abuja, a place Shekau (Boko Haram's spokesman) described as a "forum of all global evil" and their first international target (Thisday Newspaper, September 19, 2011).

Apart from their attacks on military barracks, Schools, market places and crowded city centres in the north eastern states of Borno, Yobe and Adamawa, the blood thirsty group, whose link to al-Qaeda and al-Shabbab has been exhaustively proven, has carried out isolated assaults in Kaduna and a few other Northern States.

The Boko Haram insurgents are threatening the Nigerian state and their 'successes' are unsettling the continued corporate existence of Nigeria. These characters are becoming bolder and more daring in their mindless bloodletting. The estimated number of casualties from their attack are put at 1500 in the past three months alone and it's increasing by the day and this does not include military casualties that were kept away from public glare. The frequent killings experienced in some parts of the country poses a serious security threat and also destroys community relations that existed for centuries (The Punch Newspaper, 2014).

The news coming from the North-East zone sound very strange, unbelievable and bizarre as the insurgents are said to arrive communities with scores of Hilux jeeps in the dead of the night and operate for four to five hours mostly leave the communities at the wee hours of the day without confrontation from the security forces. This leaves us with questions as, where are these cars parked? Where did the security forces go to? Who instructed them to withdraw from their duty post?

The lingering insecurity from the group's activities led to the declaration of state of emergency in May last year by President Jonathan in the three key northern states of Borno, Yobe and Adamawa which are their epic-centers. The Nigerian Military force has since swung into major operations in the North-East zone aimed at eliminating Boko Haram, which has targeted public infrastructure, forced the closure of schools, destroy local economies, killed many people and 
forced many more to flee their homes. According to the United Nations Office for the Co-ordination of Humanitarian Assistance, since 2013, Boko Haram's attack have displaced around 300,000 people, most of whom fled to other states, with many taking refuge in neighbouring countries (The Punch Newspaper, 2014:16)

On Monday, May 14, 2014, Millions of Nigerians woke up to news of man's inhumanity to man. According to The Punch Newspaper, "Security agencies have confirmed that 71 persons have so far lost their lives in the four man suicide bomb blast that occurred at a motor park in Nyanya, a satellite town of the Federal Capital Territory, Abuja, while 124 persons sustained various degrees of injuries; 16 luxury buses were razed with 24 others destroyed in the blast". The latest blood bath is just one in a series of many in a society that has got used to horror and repugnancies and all that is reprehensible about religious and political fanaticism. This paper strongly believes that the attack bears an important message for the authorities that no part of the country can claim to be safe from Boko Haram's campaign of terrorism. It is a chilling reminder that the menace of terrorism affects us all in our daily lives and that we should all be part of the fight against it.

On the same day, a total of over 234 school girls were abducted from Government Girls Secondary School Chibok in Borno state. In an aggregate, 10 or more Nigerians have been slaughtered every single day since January 1, 2014. And billions of naira in properties have been damaged or lost. As I write this, it's not even June; and December is still eight months away. Perhaps, by the end of the year, Boko Haram would have killed 20 or more Nigerians every single day. In many war-torn societies, you don't experience these many deaths and destructions (The Punch Newspaper, 2014:80). Furthermore, no other part of the world has witnessed the wanton destruction of lives in the numbers being witnessed in Nigeria, not even in Afghanistan, Sudan, Iraq and Pakistan where terrorism had taken root long before it surfaced here.

\section{Recommendation}

The Boko Haram sects and the previous groups that emerged in the past in Nigeria did not emerge out of the blues, their emergence is traceable to a lacuna in the system which the Federal Government failed to address. It is based on the above that I am recommending the following as a way forward towards managing the Boko Haram sect as well as preventing the emergence of another militant sect in the country.

(1) We call on President Goodluck Jonathan to rise up to the occasion by matching words with action as Presidential /elite visits to bomb sites and survivors is not enough. He must be proactive and pragmatic in his approach to quelling this menace. Insecurity from activities of Boko Haram has led to mass exodus of investors and businesses from the north on one hand and the exodus of foreign investors from Nigeria.

The President should also improve on the existing cooperation with neighbouring countries in the fight against this group.

(2) The Northern elites should also try to broker peace in the region as it is believed that they are lovers of peace and tranquility which the menace Boko Haram threatens, as it is only in peace that the region will witness developments. Refusal to do that, the President should fish out the sponsors of Boko Haram and invoke the full State of emergency in those states with partial emergency (Anyadike, 2013-online).

(3) The three tiers of government in the country should strive positively in the area of economic empowerment and employment generations in other to provide economic and basic needs to its teeming citizens. Provision of housing, food, education, health services, safe drinking water that will help citizens attain a minimum standard of living. It is our firm belief that if basic needs were provided for the citizenry coupled with provision of employment opportunities especially for the youths, it will minimize people's desperation and frustration that make them available for swift inducement for militancy and other social vices.

(4) The reformation of the security agencies in the country is quite paramount in the fight against insurgency attacks generally and Boko Haram in particular.

The Nigerian Police like other security agencies in the country are facing many challenges among which is corruption, inadequate welfare packages, lack of necessary materials, lack of proper orientation, conducive environment among others, which need attention by way of practical reform. To be taught correct investigative skill and professionalism because they are used to early closure of case file and happy trigger ones.

In the same vein, the Nigerian army should apply their customary vigour and dedication for which they are known to achieve victory over the menace -Boko Haram.

(5) Government should adopt dialogue and negotiation in handling up growing crisis rather than applying force. Ambassador Yusuf Mamman in an interview blamed the Boko Haram controversy on the extra judicial killings 
of their founder by the police. He argued further that if policemen were not careless in spraying innocent citizens who were not carrying any weapons with bullets, as shown on Al Jazeera Television, the problem would not have got out of control (Vanguard Newspaper, 2011). Furthermore, in suppressing peaceful protest, security agencies should stop attacking peaceful protesters with force like witnessed in Lagos during the 2012 subsidy protest.

(6) There is also the need for proper religious orientation of the citizens. It is as a matter of fact that Christian and Muslim devotees in Nigeria especially those in the Northern part need to avoid extremism in their religious practice and that both religious leaders during the cause of preaching need not be given sermon that will cause civil disturbances. No wonder John Onaiyekan the Catholic Cardinal Archbishop of Abuja stated that Christians and Muslim extremists are responsible for many of the tension between the two communities in Nigeria (The Punch Newspaper, 2012). The Cardinal further argued that most of the problems are caused by the reckless utterances and activities of extremist fringe, a group on both sides of the divide.

Similarly, religious leaders need to adopt the principle of 'live and let others live' in the cause of their preaching as some avoidable crises have been fuelled courtesy of preaching.

(7) The government should try to create a constitutional role for the traditional rulers and their institutions in the country as to help in checkmating insurgency in the nation. Nigeria's traditional institutions are well structured like a pyramid and if integrated in to the political structure, it could help to identify clandestine characters, help to solve upcoming crisis that may affect the citizenry and also help in negotiating an end to the problem.

(8) The security agencies should work together to adopt modern method of intelligence gathering and sharing of information while, the three tiers of government should employ the use of CCTV survelliance cameras in various location in the country as this could assist the police and other security operatives track down street criminals in our society and also go along way in checkmating the activities of the group.

\section{Conclusion}

There is no doubt that different militant groups have emerged in Nigeria with the Boko Haram leading the park. It has also been established that the group have posed the most serious challenges to the nation with recommendations to checkmate it.

Security challenges in Nigeria in recent times have ranged from sectarian violence in some northern parts of the country to militancy in the Niger Delta area. The spate of violent crimes in parts of the country including kidnapping, armed robbery and assassinations, were some of the contemporary security challenges facing the nation. Bomb blast and suicide terrorism is another emerging threat by some unpatriotic, undemocratic, vendors of death with cruel hearts in the country.

The Boko Haram militant group in Nigeria grew out of a 2009 riot led by its members in Maiduguri that ended in a military crackdown that killed some 700 people. The group leader died in police custody and they are fighting to get their imprisoned members freed and have strict shariah law adopted across the multi-ethnic nation of more than 160 million people. From 2010 to date, the extremist group has engaged in hit and run shooting and suicide bombing. Recently, they've begin to use military-grade weapons, some of which apparently were seized from the Nigerian military stockpiles (The Nigerian Tribune, November 2013).

The group is believed to have several splinter groups who analysts believe have contacts with two other al-Qaeda linked groups in Africa. From what started with a few fighters that 'used fuel-laden motorcycles' and 'bows with poisoned arrows' to attack police stations has now escalated to an all-out war on Nigerians and foreigners alike. As it stands today, the group move in a convoy of Hilux -Jeeps, well armed fighters with multiple AK 47 guns, assorted rifles and many technicians who are bomb experts. The unfolding dimensions of Boko Haram threat to national security are challenges that must be confronted headlong and defeated at all cost as it's a huge challenge on life and property as well. Citizens have been denied the choice of exercising their natural freedom of movement due to fear of attack from members of the group.

It is the belief of this paper that the Boko Haram group is not a political movement, nor a religious one, but an evil group. It is therefore imperative that all Nigerians and friends of Nigerians join in this fight to rid our country of this menace that is threatening to tear our unity. 


\section{References}

Anyadike, N. (2013) Boko Haram And National Security Challenges in

Nigeria; Causes And Challenges (Online).

Buzan, B. (1992) People, State and Fear, New York: Harvest Wheatsheaf

Press.

Da'wah Coordination of Council Nigeria "The Bokn Haram Tragedy", by DCCN, Mnna, Niger State, 2009.

Ekanem, Dada \& Ejue, (2012) "Boko Haram And Amnesty: A Philo-Legal Appraisal", New York.

Galtung, J. (1982) Environment, Development And Military Activity: Towards Alternative Security Doctrine, Columbia: Columbia University Press

Gambo, A. (2008) Conflicts In The Niger Delta And National Security In Nigeria. Jos: Mono Expressions Ltd.

Gurt, G. (1985) Searching For World Security: Understanding Global Armament And Disarmament, London: Frances Publisher.

Imobighe, T. (1992) "Chasing The Shadow: Illusory Battle For Law, Order and Security In Nigeria" In Siddique And Tony (eds) Nigeria: A Republic In Ruins, Zaria: Gaskiya Corporatins Ltd.

Imobighe, T. (1998) The Management Of National Security, Ekpoma: Edo State University Publishing House.

Ivor, R. (1996) "Security Strategy In Africa: Why Peace-keeping"? In Vost and Aminu (eds) Peace keeping As Security Strategy In Africa: Chad And

Liberia As Case Studies, Enugu: Fourth Dimension Publishing Company Ltd.

McNamara, R. (1968) The Essence Of Security, New York: New York Press

Mesjasz, C. (2004) Security As An Analytical Concept, Hague. www.afes- Press.de/pdf/Hague/Mesjasz-Security-Concept.pdf

Owalade, F. (2014) http//www.gatestoneinstitute.org/4232/boko-haram- nigeria, accessed 24th March, 2014.

Padelford, N. (1976) The Dynamics Of International Politics: New York: Macmillan Publishing Company.

Renner, M. (1990)"The Drain Of The Permanent War Economics" In Suzanne (eds) World Politics, New York Dusking Publishers.

The Nation (Lagos) Newspaper 2013

The Nigerian Tribune (Lagos) Newspaper 2013

The Punch (Lagos) Newspaper 2012

The Punch (Lagos) Newspaper 2014

The Vanguard (Lagos) Newspaper 2011

Walt, K. (1979) The Theory Of International Politics, Addison: Wesley Reading Mass.

Wikipedia-http://en.wikipedia.org/wiki/Boko Haram(14/4/14)

Zabadi, S. (2005) Understanding Security And Security Sector DynamicsBaltimore: John Hopkins University Press. 